\title{
制御弁式鉛蓄電池正極集電体への ペロブスカイト型酸化物皮膜の形成とその防食効果
}

\author{
下浦 一朗*a，寺田 正幸 ${ }^{a}$, 山口 豊a, 高島 正之 ${ }^{b}$ \\ a新神戸電機(株) 技術開発本部名張研究所（テ518-0493 名張市八幡 1300-15） \\ b福井大学工学部材料開発工学科（下 910-8507 福井市文京 3-9-1）
}

\section{Formation and Anti-corrosive Effect of Perovskite Oxide Films on the Surface of Cathode Grid for Valve Regulated Lead Acid Battery}

\author{
Ichiro SHIMOURA, *a Masayuki TERADA, a Yutaka YAMAGUCHI, a and Masayuki TAKASHIMA ${ }^{\mathrm{b}}$
}

\begin{abstract}
${ }^{a}$ Nabari Research Laboratory, Reserch \& Development Div., Shin-Kobe Electric Machinery Co., Ltd. (Yabata 1300-15, Nabari, Mie 518-0493, Japan)

bDepartment of Materials Science and Engineering, Faculty of Engineering, University of Fukui (Bunkyo 3-9-1, Fukui 910-8507, Japan)
\end{abstract}

Received December 24, 1999 ; Accepted July 18, 2000

\begin{abstract}
One of the most important problems to develop the long-lived valve regulated lead acid battery is the intergranular corrosion of the cathode grid made of $\mathrm{Pb}-\mathrm{Ca}$-Sn alloy during trickle charging. To prevent the corrosion, the electroconductive perovskite type oxide films containing lead metal were formed on the surface of the cathode grid. As the results of surveying various systems between $\beta$-type lead oxide $\left(\beta-\mathrm{PbO}_{2}\right)$ and metal oxides or hydroxides, it was confirmed tha $\mathrm{BaPbO}_{3}$ and $\mathrm{SrPbO}_{3}$ were formed even at $300^{\circ} \mathrm{C}\left(\mathrm{mp}\right.$ of $\mathrm{Pb}-\mathrm{Ca}-\mathrm{Sn}$ alloy, $\left.320^{\circ} \mathrm{C}\right)$. The life of trickle-charging test of the battery with the cathode, of which grid was covered with $\mathrm{SrPbO}_{3}$, was twice longer than that of the standard battery without the perovskite oxide treatmeat.
\end{abstract}

Key Words : Valve Regulated Lead Acid Battery, Perovskite Type Oxide Films, Intergranular Corrosion, Life of TrickleCharging Test

\section{1 緒 言}

近年の情報化時代を反映して，無停電電源装置（UPS）や 各種通信機器のバックアップ用電源として制御弁式鉛蓄電池 の需要が増加している．それにともない，より高性能な電池 の開発が急がれている.UPSやバックアップ用電源など連 続充電状態におかれる制御弁式鉛蓄電池は，電槽からの透湿 による電解液の滅少, 集電体腐食による正極集電体の伸びお よび活物質の脱落等により容量低下および短絡などで寿命に 達する，特に，集電体の腐食は，最も大きな問題であり，長 寿命化を図る上では，この集電体の腐食を抑制することが非 常に重要である。

集電体の腐食を抑制するには(1)電解液である希硫酸の濃度 を下げる(2)集電体の合金組成の最適化 ${ }^{1-3)}$ または結晶組織 の制御 $4 ， 5)$ (3)集電体上に耐食性の皮膜を形成するといった 手段が有効と考えられている6-9). そこで, 導電性を有し， 化学的安定性の高い鉛を含むぺロブスカイト型酸化物 $\left(\mathrm{MPbO}_{3}\right)$ に着目し，耐食性皮膜となる新たな複合酸化物の 合成および生成過程の検討と表面にその皮膜を形成した $\mathrm{Pb}$ Ca-Sn 合金の集電体の耐食性と寿命延長効果について検討を 行った.

\section{2 実 験}

\section{1 粉体系でのペロブスカイト型酸化物の合成}

集電体表面にペロブスカイト型酸化物皮膜を形成するため に, 集電体の融点 $\left(320^{\circ} \mathrm{C}\right)$ 以下の温度での処理を試みた。 出発物質として Fig. 1 に示したアルカリ土類金属, ランタニ ド金属及びオキソ酸を形成する元素を中心に選択し，その水 酸化物及び酸化物の 40 種について固相反応による合成を試 みた，鉛蓄電池用正極活物質 $\beta-\mathrm{PbO}_{2}$ と各種金属水酸化物

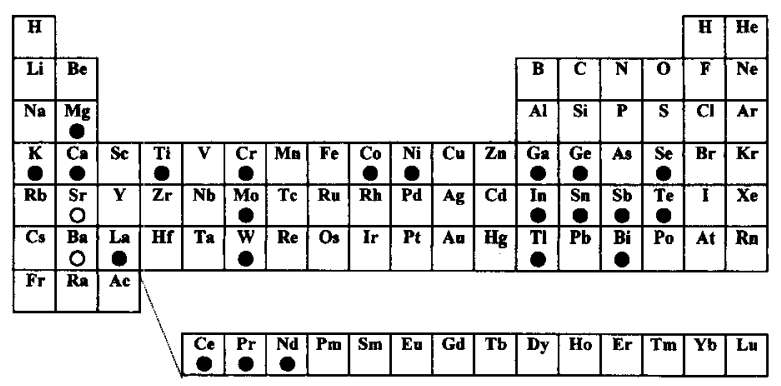

Fig. 1 Elements $(\mathrm{M})$ of $\beta-\mathrm{PbO}_{2}-\mathrm{MO}_{\mathrm{x}}$ or $\mathrm{M}(\mathrm{OH})_{\mathrm{x}}$ to prepare the perovskite type oxide at $300^{\circ} \mathrm{C}$ in air for $8 \mathrm{~h}$.

$\mathrm{O}$ : perovskite oxide formed, $\mathrm{O}$ : perovskite oxide unformed. 
Table 1 XRD pattern of $\beta-\mathrm{PbO}_{2} . D_{\mathrm{hkl}}$ : crystalite size.

\begin{tabular}{c|ccc|ccc}
\hline Kind of $\beta-\mathrm{PbO}_{2}$ & \multicolumn{3}{|c|}{$2 \theta=25.44$ deg. } & \multicolumn{3}{|c}{$2 \theta=32.02$ deg. } \\
& $\begin{array}{c}\text { Intensity FWHM } \\
\text { (cps) }\end{array}$ & $\begin{array}{c}D_{110} \\
\text { (radian) }\end{array}(\AA)$ & Intensity FWHM & $D_{110}$ \\
(cps) & (radian) $(\AA)$ \\
\hline $\begin{array}{c}\text { Ehemical } \\
\text { synthesized }\end{array}$ & 5765 & 0.12 & 669 & 4866 & 0.14 & 594 \\
\hline $\begin{array}{c}\text { Electrochemical } \\
\text { synthesized }\end{array}$ & 1683 & 0.18 & 446 & 1656 & 0.20 & 417 \\
\hline
\end{tabular}

（もしくは酸化物）を金属元素比が $1: 1$ の割合になるように 精科し，アルミナ製乳鉢を用いて粉砕混合した。混合物約 $4 \mathrm{~g}$ を磁製皿 $($ W $50 \times \mathrm{L} 30 \times \mathrm{H} 10 \mathrm{~mm})$ に充填し, 電気炉

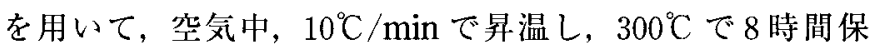
持し，その後室温まで自然放冷した。

$\beta \cdot \mathrm{PbO}_{2}$ には, 電気化学的に合成されたものと, 化学合成 されたものとでは, その粒子形態, 結晶性等の特性が異なる ことが知られている. Table 1 に, 本実験で用いた $\beta-\mathrm{PbO}_{2}$ のXRD 測定結果を示す。化学合成したものは回折強度が高 く, 半価幅も小さい. 一方, 電気化学合成したものは, 前者 に比べ回折強度が小さく，半価幅の大きい $\beta-\mathrm{PbO}_{2}$ であった， 本実験では $\beta-\mathrm{PbO}_{2}$ の形態の違いによる複合酸化物の反応性 の影響を確認するために，粉体試料にて比較検詩した。

\section{2 集電体への耐食性皮膜の生成}

粉体系での結果をもとに実際の正極集電体表面への $\mathrm{SrPbO}_{3}$ および $\mathrm{BaPbO}_{3}$ の形成を試みた。正極集電体の組成 は $\mathrm{Pb}-0.08 \mathrm{wt} \% \mathrm{Ca}-1.00 \mathrm{wt} \% \mathrm{Sn}$ であり, 集電体 $(\mathrm{W} 30 \times \mathrm{L}$ $20 \times \mathrm{T} 0.8 \mathrm{~mm})$ を $32 \mathrm{wt} \%$ の希硫酸中にて電流密度 $1.0 \mathrm{~mA}$ $\mathrm{cm}^{2}$ で 3 時間陽極酸化させた。この $\mathrm{PbO}_{2}$ 皮膜が表面に形成 した集電体を水洗乾燥後, 磁製而に載せ乳鉢にて粉砕した $\mathrm{Sr}(\mathrm{OH})_{2} \cdot 8 \mathrm{H}_{2} \mathrm{O}$ もしくは $\mathrm{Ba}(\mathrm{OH})_{2} \cdot 8 \mathrm{H}_{2} \mathrm{O}$ 粉体中に埋め 込み, 空気中, $10^{\circ} \mathrm{C} / \mathrm{min}$ で昇温し, $300^{\circ} \mathrm{C}$ での 8 時間加熱 処理を行なった. 皮膜形成後, 集電体に活物質ペーストを叙 布し熟成乾燥後, 化成処理したものを正極板として用いた. 活物質ペーストは，PbO を主成分とする鉛粉に水と希硫酸 を加え, $15 \% \mathrm{PbSO}_{4}$, 残分 $\mathrm{PbO}$ からなるペーストを作成し た. 熟成乾燥条件は, 温度 $30^{\circ} \mathrm{C}$, 相対湿度 $98 \%$ で 24 時間 熟成乾燥を行なった．また，化成処理は課電量 $200 \%$ で 20 時間化成を行なった。

\section{3 腐食試験}

極板の耐食性の評価には，ポテンショスタットを用いた定 電位腐食試験を行なった。 ポテンショスタットには北斗電工 製 POTENTIOSTAT/GALVANOSTAT HA-151を用いた。 試験条件をTable 2 に示した。この場合の定電愔腐食試験は， 定電位充電に相当し, 観測される電流值は腐食電流と充電電 流の和である。

また，皮膜処理を施した極板を用いて 6 V-6 Ahの制御弁

Table 2 Condition of constant potential corrosion test.

\begin{tabular}{c|c}
\hline Plate size & $30 \times 30 \times 4 \mathrm{~mm}$ \\
\hline $\mathrm{H}_{2} \mathrm{SO}_{4}$ concentration & $42 \mathrm{wt} \%$ \\
\hline Temperature & $71^{\circ} \mathrm{C}$ \\
\hline Potential & $1.240 \mathrm{~V}$ vs. $\mathrm{Hg} / \mathrm{Hg}_{2} \mathrm{SO}_{4}$ \\
\hline
\end{tabular}

式電池を作製し， $71^{\circ} \mathrm{C}, 2.23 \mathrm{~V} /$ セルの条件でトリクル充電 寿命試験を行った．電池の初期容量は定電流放電 $(0.25 \mathrm{C})$ で確認した。また，寿命試験中は，約 2 週間毎に定電流放電 $(0.25 \mathrm{C})$ で容量を確認し, 減少した分の水を補給し, 制限 電流 $0.3 \mathrm{CA}, 2.45 \mathrm{~V} /$ 七ルの定電圧充電を $16 \mathrm{~h}$ 行った.

試験後の集電体の腐食状況をみるために，試験後の極板を エポキシ樹脂に埋め込み，断面を観察した.

ペロブスカイト型酸化物の確認は，X線回折法を用いた $\left(\mathrm{Cu}-\mathrm{K}_{\alpha}, 40 \mathrm{kV}, 30 \mathrm{~mA} \text {; マックサイエンス社製 } \mathrm{MXP}^{3}\right)^{10)}$.

熱重量・示差熱分析 (セイコー電子工業(株)製 $\mathrm{TG} /$ DTA32）を用いて $\mathrm{PbO}_{2}$ 粉末とアルカリ土類金属水酸化物と の反応過程を調べた ${ }^{11)}$ ， $\mathrm{PbO}_{2}$ とアルカリ土類金属水酸化物 をモル比 $1: 1$ で混合した試料 $10 \mathrm{mg}$ を空気中， $10^{\circ} \mathrm{C} / \mathrm{min}$ 昇温し， $1200^{\circ} \mathrm{C}$ まで測定した，基準物質には $\alpha-\mathrm{Al}_{2} \mathrm{O}_{3}$ を用 いた.

X 線光電子分光分析装置 (XPS，島津製作所製 ESCA-850 M)を用いて生成した複合酸化物の酸化状態を調べた。XPS の高速イオン銃によるエッチング速度約 $80 \mathrm{~nm} /$ 分で深さ方 向の分析を行なった。

$\mathrm{X}$ 線マイクロアナライザー（明石製作所製 EPMA， AL PHA $30 \mathrm{~W})$ を用いて，皮膜中の元素の分布状態を調べた. 試料極板を水洗, 乾燥後, エポキシ樹脂に包埋し，ダイヤモ ンドカッターで切断後, 断面をエメリー紙及びバフで研磨し て観察試料とした。

また，金属顕微鏡を用いて極板の界面，集電体腐食等を観 察した。

\section{3 結果および考察}

\section{1 ペロブスカイト型酸化物の合成}

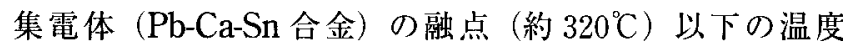
でも合成可能なぺロブスカイト型酸化物を探索するために,

Fig. 1 中に○印と○印をした元素の水酸化物及び酸化物の 40 種について， $300^{\circ} \mathrm{C} て ゙ 8 h の$ 焼成実験を試みた。その結果, ○印のアルカリ土類金属（ $\mathrm{Sr}, \mathrm{Ba})$ では副生成物の生成, $\beta-\mathrm{PbO}_{2}$ の残留も認められたがこれらアルカリ土類金属を含 むぺロブスカイト型酸化物が合成され，○印の元素の水酸化 物及び酸化物では，合成されないことがわかった，X 線回折 四の結果より，○印の元素の化合物を用いた場合には，生成 物は $\mathrm{PbO}_{2}$ と用いた金属の酸化物の混合物であることがわか った，そこで，以下では合成可能であった， Ba 及び $\mathrm{Sr}$ 系の ペロブスカイト型酸化物について検討することにした。

\section{2 ペロブスカイト型酸化物皮膜の生成}

Fig. 2 及びFig. 3 に焼成後の生成物全てを粉砕混合した試 料の X 線回折図を示す.

化学合成 $\beta \cdot \mathrm{PbO}_{2}$ を用いた場合では，ペロブスカイト型酸 化物の $\mathrm{BaPbO}_{3}$ の他に, $\mathrm{Ba}$ と $\mathrm{Pb}$ の複合酸化物である $\mathrm{Ba}_{2}$ $\mathrm{PbO}_{4}$ および $\alpha-\mathrm{PbO}_{2}$ の生成が確認されたが, $\beta-\mathrm{PbO}_{2}$ も多 く残留していることがわかった。一方, 電気化学合成 $\beta-\mathrm{PbO}_{2}$ を用いた場合は, 化学合成 $\beta-\mathrm{PbO}_{2}$ を用いた場合よ りも $\mathrm{BaPbO}_{3}$ の生成した量が多かった。 また，実際の電池 の集電体を想定し，解析が容易にできるように $\mathrm{Pb}-\mathrm{Ca}-\mathrm{Sn}$ 合 金からなる板を陽極酸化し，ペロブスカイト型酸化物の合成 を試みた結果を Fig.2（c）に示す．陽極酸化した $\mathrm{Pb}$ 板の場 合， $\mathrm{BaPbO}_{3}$ の生成が認められた。また，Fig. 3 に示すよう に $\mathrm{Sr}(\mathrm{OH})_{2} \cdot 8 \mathrm{H}_{2} \mathrm{O}$ を用いた場合に打いても電気化学 

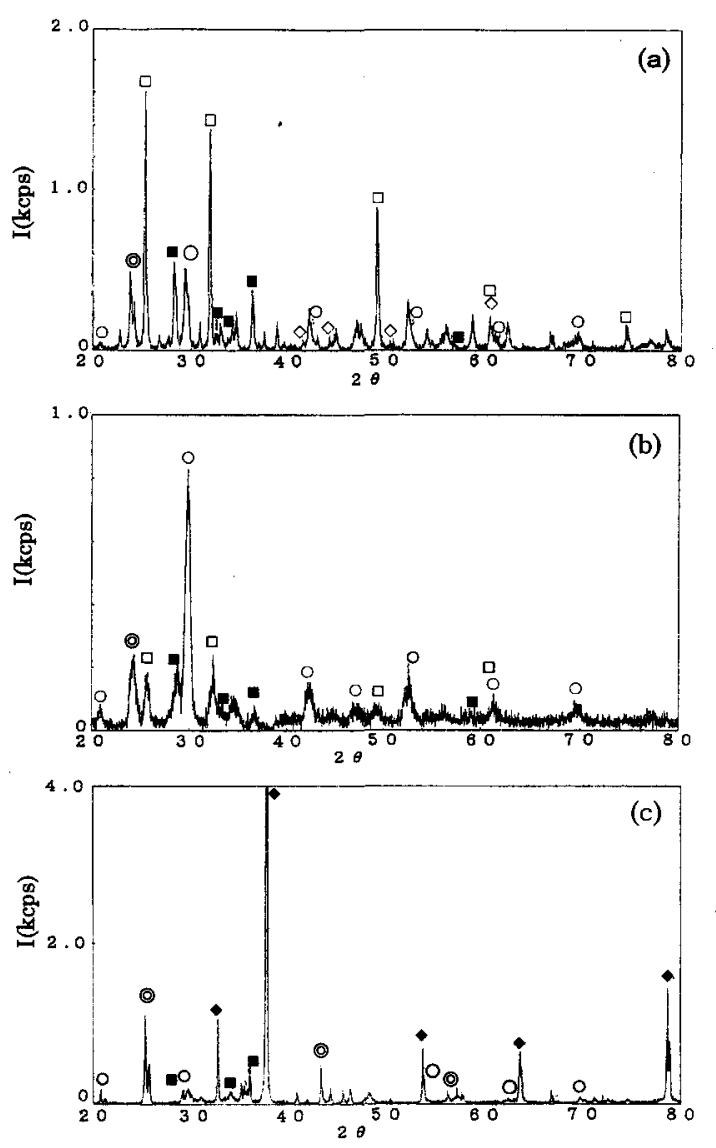

Fig. 2 XRD Profiles of the products from $\mathrm{Ba}(\mathrm{OH})_{2} \cdot 8 \mathrm{H}_{2} \mathrm{O}$ and various $\mathrm{PbO}_{2}$ at $300^{\circ} \mathrm{C}$ in air for $8 \mathrm{~h}$.

(a): $\beta-\mathrm{PbO}_{2}$ (chemical synthesized) $+\mathrm{Ba}(\mathrm{OH})_{2} \cdot 8 \mathrm{H}_{2} \mathrm{O}$, (b): $\beta-\mathrm{PbO}_{2}$ (electrochemical synthesized) $+\mathrm{Ba}(\mathrm{OH})_{2} \cdot 8 \mathrm{H}_{2} \mathrm{O}$, (c): $\mathrm{PbO}_{2}$ (on $\mathrm{Pb}$ sheet) $+\mathrm{Ba}(\mathrm{OH})_{2} \cdot 8 \mathrm{H}_{2} \mathrm{O}, \bigcirc: \mathrm{BaPbO}_{3}, \diamond$ : $\mathrm{Ba}_{2} \mathrm{PbO}_{4}, \square: \alpha-\mathrm{PbO}_{2}, \square: \beta-\mathrm{PbO}_{2},-\mathrm{Pb},(\mathrm{O})$ : unknown.

$\beta-\mathrm{PbO}_{2}$ を用いたほうが, $\mathrm{Sr}$ 系でもぺロブスカイト型酸化物 が生成しやすいことがわかった.

Table 1 に本試験で用いた $\beta-\mathrm{PbO}_{2}$ の X 線回折結果を示す. Table $1 よ り$, 化学合成 $\beta-\mathrm{PbO}_{2}$ に比べ, 電気化学合成 $\beta-\mathrm{PbO}_{2}$ は回折強度が小さく, 半価幅から Scherrerの式よ り求めた結晶サイズも小さい。また，電気化学合成した $\mathrm{PbO}_{2}$ は結晶構造中にプロトンを多く含んでいる12-15)ために 結晶成長が進まず, アモルファス構造に近くなり ${ }^{16)}$, その結 果反応性が高いと考えられている.

以上, $\mathrm{Pb}-\mathrm{Ca}-\mathrm{Sn}$ 合金の融点以下の温度である $300^{\circ} \mathrm{C} て ゙ も$, ペロブスカイト型酸化物の合成が可能であることがわかった。

Fig. 4 は $\mathrm{Ba}(\mathrm{OH})_{2} \cdot 8 \mathrm{H}_{2} \mathrm{O}, \beta-\mathrm{PbO}_{2}$ 扝よびBa $(\mathrm{OH})_{2} \cdot 8 \mathrm{H}_{2} \mathrm{O}$ と $\beta-\mathrm{PbO}_{2}$ の混合物の TG, DTA曲線である. $\mathrm{Ba}(\mathrm{OH})_{2}$. $8 \mathrm{H}_{2} \mathrm{O}$ について, $100^{\circ} \mathrm{C}$ 付近での重量減少および吸熱ピーク は $7 \mathrm{H}_{2} \mathrm{O}$ の脱離に対応しており, 約 $120^{\circ} \mathrm{C} て ゙ の$ 変化は $\mathrm{Ba}(\mathrm{OH})_{2}$ への, さらに約 $1080^{\circ} \mathrm{C}$ でのそれは $\mathrm{BaO} へ の$ 変化 に対応している，一方， $\beta-\mathrm{PbO}_{2}$ については，以下のように 文献で報告されている結果17)の通りであることが確認され た. $400^{\circ} \mathrm{C}$ 付近より徐々に酸素の脱離が始まり，560兄以上 で $\mathrm{PbO}$ となった. $900^{\circ} \mathrm{C}$ 以降の変化については, $\mathrm{PbO}$ の融 点が $897^{\circ} \mathrm{C}$ であることから, $\mathrm{PbO}$ の融解，蒸発が起こった ものと考えられる. $\mathrm{Ba}(\mathrm{OH})_{2} \cdot 8 \mathrm{H}_{2} \mathrm{O}$ と $\beta-\mathrm{PbO}_{2}$ の混合 物, $100^{\circ} \mathrm{C}$ 付近での重量減少および吸熱ピークは
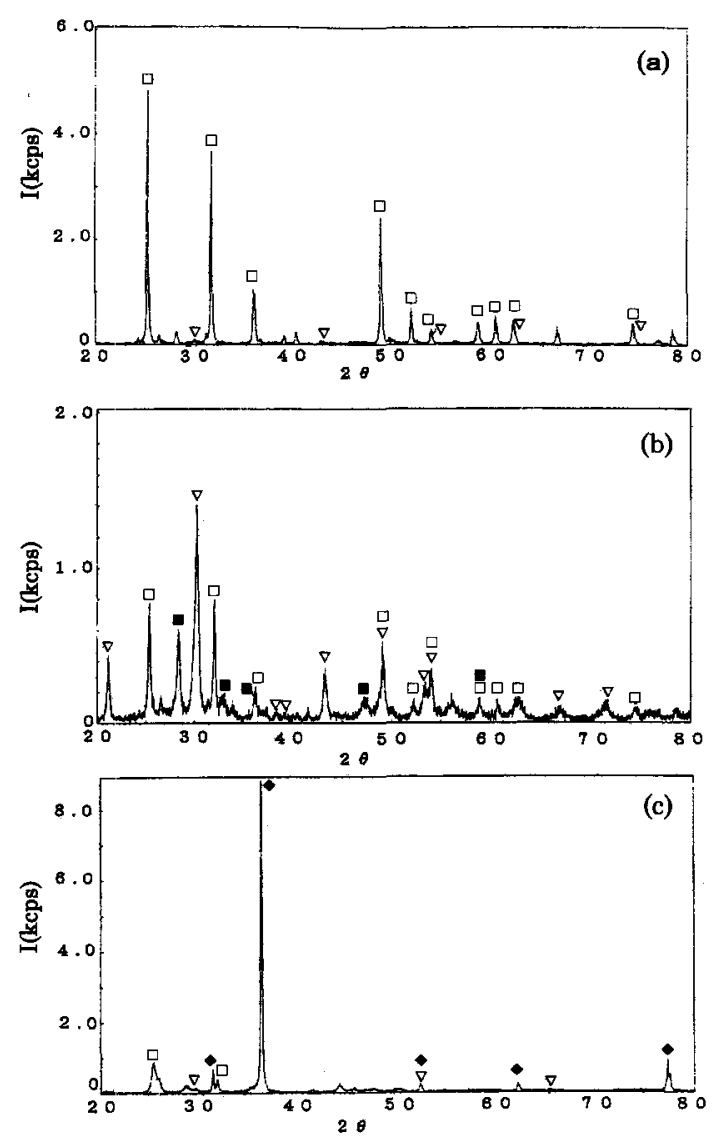

Fig. 3 XRD Profiles of the products from $\mathrm{Sr}(\mathrm{OH})_{2} \cdot 8 \mathrm{H}_{2} \mathrm{O}$ and various $\mathrm{PbO}_{2}$ at $300^{\circ} \mathrm{C}$ in air for $8 \mathrm{~h}$.

(a): $\beta$ - $\mathrm{PbO}_{2}$ (chemical synthesized) $+\mathrm{Sr}(\mathrm{OH})_{2} \cdot 8 \mathrm{H}_{2} \mathrm{O}$, (b): $\beta-\mathrm{PbO}_{2}$ (electrochemical synthesized) $+\mathrm{Sr}(\mathrm{OH})_{2} \cdot 8 \mathrm{H}_{2} \mathrm{O}$, (c): $\mathrm{PbO}_{2}$ (on $\mathrm{Pb}$ sheet) $+\mathrm{Sr}(\mathrm{OH})_{2} \cdot 8 \mathrm{H}_{2} \mathrm{O}, \nabla: \mathrm{SrPbO}_{3}, \mathbf{a}: \alpha-\mathrm{PbO}_{2}$, $\square: \beta-\mathrm{PbO}_{2}, \bullet: \mathrm{Pb}$.

$\mathrm{Ba}(\mathrm{OH})_{2} \cdot 8 \mathrm{H}_{2} \mathrm{O}$ の場合と同じく, $7 \mathrm{H}_{2} \mathrm{O}$ の脱離に対応し て扔り, 約 $370^{\circ} \mathrm{C}$ 付近より $\mathrm{BaPbO}_{3}$ の生成と思われる重量 滅少を伴う吸熱ピークが認められた。 また, $1000^{\circ} \mathrm{C}$ 以上で 大きな重量隇少が認められたが，これについては未反応物も しくは $\mathrm{BaPbO}_{3}$ の分解と考えられるが確認はできていない.

熱分析の結果をもとに, 焼成温度が 350,500 および $650^{\circ} \mathrm{C}$ の場合での生成物の違いを調べた。 また，焼成時の雾 用気の影響を調べるために空気中と $\mathrm{Ar}$ 気流中にて焼成を行 った. Fig. 5 は各温度で焼成した生成物のX線回折図である. 温度が高くなるにつれて $\mathrm{BaPbO}_{3}$ の回折ピークが増大し， 空気中では $650^{\circ} \mathrm{C}$ 以上では $\mathrm{BaPbO}_{3}$ の単一相が形成される. 一方, $\mathrm{Ar}$ 気流中では $\mathrm{BaPbO}_{3}$ の単一相は得られず, $\mathrm{BaPbO}_{3}$ 単一相の形成には酸素の供給が不可欠であることが わかった.

次に, $\mathrm{BaPbO}_{3}$ 皮膜を形成した集電体に関して, EPMA 分析によって $\mathrm{BaPbO}_{3}$ 皮膜の厚みおよび分布を調べた.

Fig. 6 は, $\mathrm{BaPbO}_{3}$ 皮膜を形成した集電体を用いた極板の断 面についての EPMA 分析結果である。集電体と活物質との 境界に，厚さ $1 \sim 2 \mu \mathrm{m} の \mathrm{Ba}$ を含んだ化合物の膜が部分的 に存在している.

\section{3 ペロブスカイト型皮膜の耐食性評価}

Fig. 7 に, 定電位腐食試験時の電流值の推移を示した. 試 験開始から40日目までの腐食電流については, 化成後に残 

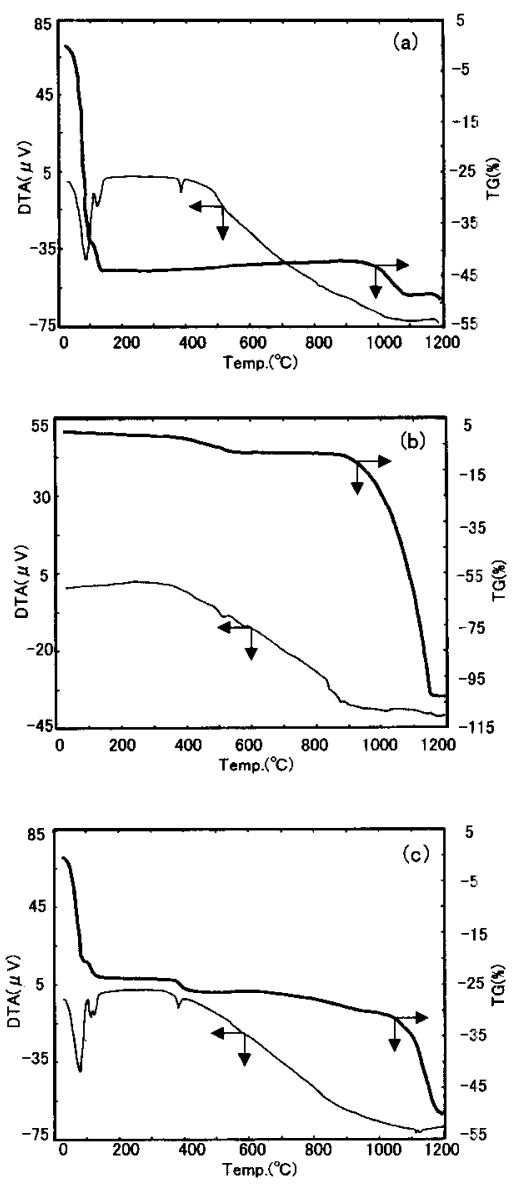

Fig. 4 TG/DTA profiles. (a) $\mathrm{Ba}(\mathrm{OH})_{2} \cdot 8 \mathrm{H}_{2} \mathrm{O}$, (b) $\beta-\mathrm{PbO}_{2}$, (c) $\mathrm{Ba}(\mathrm{OH})_{2} \cdot 8 \mathrm{H}_{2} \mathrm{O}+\beta-\mathrm{PbO}_{2}$.
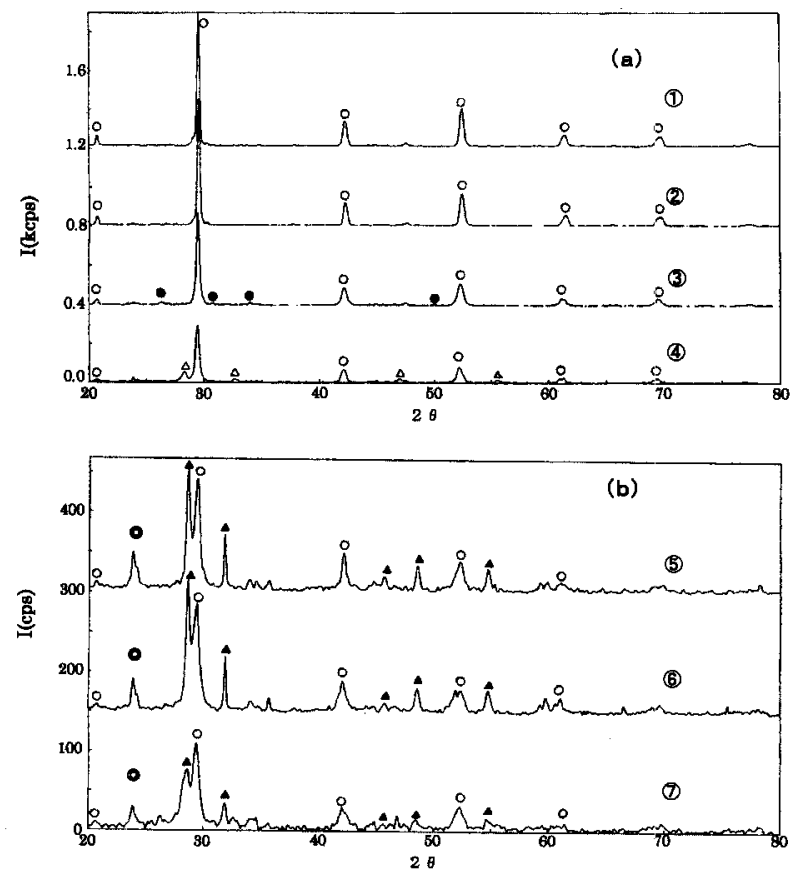

Fig. $5 \mathrm{XRD}$ Profiles of the products from $\mathrm{Ba}(\mathrm{OH})_{2} \cdot 8 \mathrm{H}_{2} \mathrm{O}$ and $\beta-\mathrm{PbO}_{2}$ (electrochemical) at various temperature in air (a) or Ar (b) for $8 \mathrm{~h}$.

(1): at $650^{\circ} \mathrm{C}$ (rapid cooled), (2): $650^{\circ} \mathrm{C}$, (3): $500^{\circ} \mathrm{C}$, (4): $350^{\circ} \mathrm{C}$, (5): $650^{\circ} \mathrm{C}$, (6): $500^{\circ} \mathrm{C},(7): 350^{\circ} \mathrm{C} . \bigcirc: \mathrm{BaPbO}_{3}, \mathrm{ObO}_{1.33}, \triangle$ : $\mathrm{PbO}_{1.44}$, $\mathbf{A}$ : $\mathrm{PbO}$, (O): unknown.

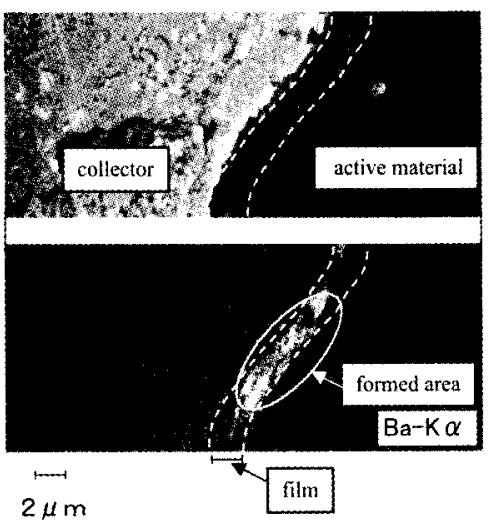

(a)

(b)

Fig. 6 SEM(a) and EPMA(b) photographs of the cross section of the $\mathrm{BaPbO}_{3}$-treating cathode plate.

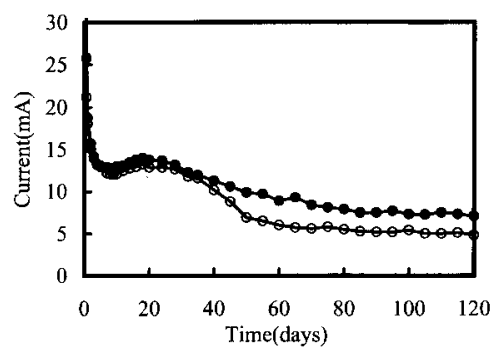

Fig. 7 The time dependency of the current at the constant potential charge corrosion test. $\mathrm{O} \mathrm{BaPbO}_{3}$ untreated, $\mathrm{O}$ : $\mathrm{BaPbO}_{3}$ treated.

存した $\mathrm{PbSO}_{4}$ の酸化による影響が大きく，皮膜の有無によ る顕著な差は現れていない。しかしながら，試験開始 40 日 以降では, $\mathrm{BaPbO}_{3}$ 皮膜品は未処理品と比べ腐食電流を含む 充電電流值が小さく, 試験開始 120 日後で未処理品の約 $2 / 3$ の值であった。正確な皮膜量については未確認であるが，こ の充電電流值の差は，皮膜処理によって集電体の腐食が抑制 された結果と考えられる。

また本試験開始 120 日後の極板を樹脂埋めし, 断面を切り 出して集電体の腐食状態を観察した. Fig. 8 は, 腐食試験後 の極板の格子状集電体内骨部分の断面写真である.ペロブス カイト型皮膜を表面に形成していない通常の集電体（a）は， $\mathrm{Pb}-\mathrm{Ca}$ 合金特有の粒界腐食がみられ，腐食が内部まで進行し， 集電体中心部分まで貫通しているのがわかる.一方， $\mathrm{BaPbO}_{3}$ 皮膜処理品（b）では未処理品にみられた粒界腐食 は認められない。

Fig. 9 に，トリクル充電寿命試験の結果を示す. 実電池系 では Sr系のみについて実施した，標準品の電池は，90日で 寿命となったが，集電体を皮膜処理した電池では，正確な $\mathrm{SrPbO}_{3}$ 皮膜量は未確認であるが, 約 2 倍の長寿命となるこ とがわかった。なお，これら制御弁式鉛蓄電池の寿命原因は ともに正極集電体の腐食による短絡であった。

\section{4 耐食性発現機構}

Fig. 10 に耐食性発現の機構を考えた。制御弁式鉛蓄電池 の正極集電体に用いられる $\mathrm{Pb}-\mathrm{Ca}$ 合金は粒界腐食する．合 金における粒界は，電気化学的にアノーディックであって， 優先的に腐食される ${ }^{18)}$. また, $\mathrm{Sn}$ P $\mathrm{Pb}_{3} \mathrm{Ca}$ などが偏析する ことで, ガルバニ電池が形成され，腐食しやすいといわれて いる(8).

通常の集電体の場合，時間の経過と共に電解液中の $\mathrm{OH}$ 

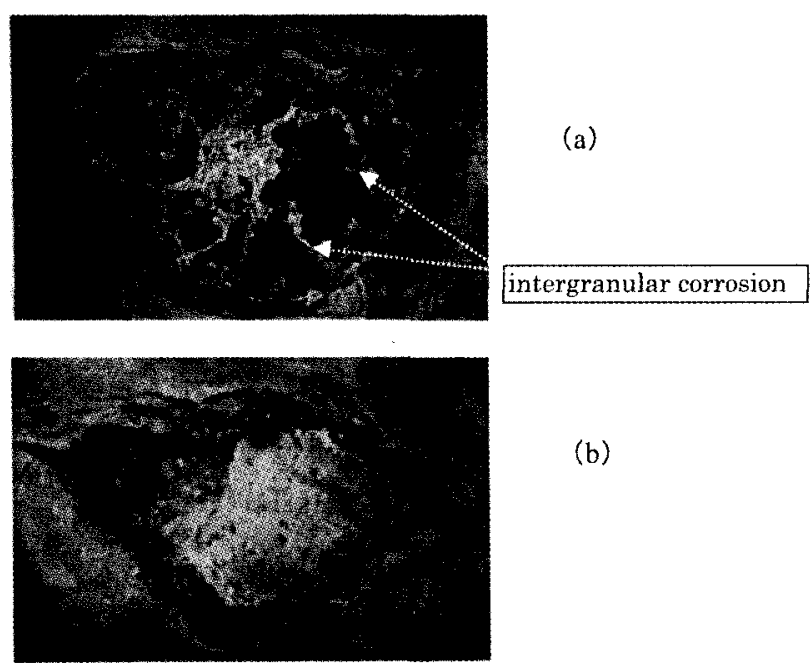

(b)

$10 \widehat{0 \mu m}$

Fig. 8 Microscope photographs of the cross section of $\mathrm{BaPbO}_{3}$ untreated plate(a) and $\mathrm{BaPbO}_{3}$ treated plate(b) after the constant potential corrosion test for 120 days.

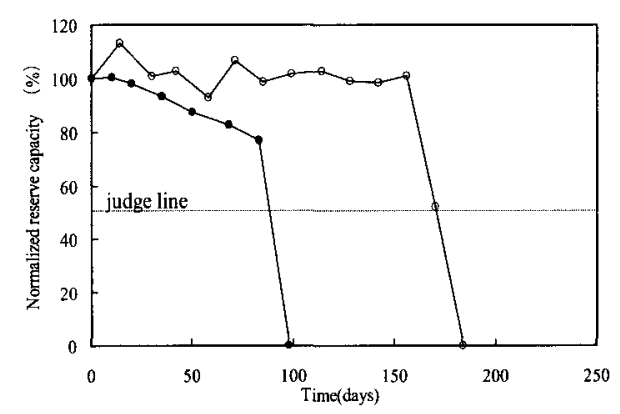

Fig. 9 Normalized reserve capacity as a function of time at the trickle charge life test.

(O): $\mathrm{SrPbO}_{3}$ treated, (O): $\mathrm{SrPbO}_{3}$ untreated.

や $\mathrm{SO}_{4}{ }^{2-}$ が集電体近傍に到達する. 到達した $\mathrm{OH}^{-} や \mathrm{SO}_{4}{ }^{2-}$ によって選択的に粒界が腐食され，これが内部まで進行して w<19).

一方，耐食性皮膜処理においても，陽極酸化は粒界面で起 こりやすいと考えられる．粒界面で $\mathrm{PbO}_{2}$ が多く生成してい るために，焼成過程に拈けるペロブスカイト型酸化物は粒界 面で多く生成しやすいと考えられる。すすおちペロブスカイ 卜型酸化物が粒界面に存在することにより， $\mathrm{Pb}-\mathrm{Ca}$ 合金特有 の粒界腐食を抑制しているものと考えられる。

\section{4 結 言}

長寿命制御弁式鉛蓄電池の正極集電体の耐食性皮膜につい て検討し，次の結果を得な。

(1) 集電体である $\mathrm{Pb}-\mathrm{Ca}-\mathrm{Sn}$ 合金の融点以下である $300^{\circ} \mathrm{C} の$ 固相反応で, $\beta-\mathrm{PbO}_{2}-\mathrm{MOx}, \quad \beta-\mathrm{PbO}_{2}-\mathrm{M}(\mathrm{OH})_{2}(\mathrm{M}=\mathrm{Mg}$, $\mathrm{K}, \mathrm{Ca}, \mathrm{Ti}, \mathrm{Cr}, \mathrm{Co}, \mathrm{Ni}, \mathrm{Ga}, \mathrm{Ge}, \mathrm{Se}, \mathrm{Sr}, \mathrm{Mo}$, In, $\mathrm{Sn}, \mathrm{Sb}, \mathrm{Te}, \mathrm{Ba}$, La, Ce, Pr, Nd, W, Tl, Bi) に ついて検討したところ，Baだけでなく $\mathrm{Sr}$ でもペロブス カイト型酸化物が生成することがわかった。

（2）反応物質である $\beta-\mathrm{PbO}_{2}$ は，化学的に合成するよりも電 気化学的に合成する方がペロブスカイト型酸化物は合成 しやすいことがわかった。

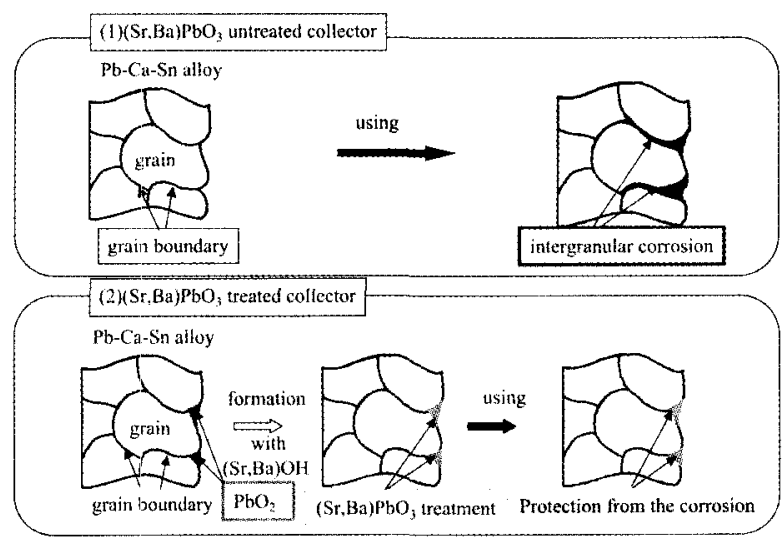

Fig. 10 Mechanism of the anticorrosion occurrence.

(3) $\mathrm{Sr}(\mathrm{OH})_{2} \cdot 8 \mathrm{H}_{2} \mathrm{O}$ もしくは $\mathrm{Ba}(\mathrm{OH})_{2} \cdot \dot{8} \mathrm{H}_{2} \mathrm{O}$ 粉体中に 埋没し，集電体鉛合金の融点以下の温度である $300^{\circ} \mathrm{C} て ゙ ，$ 集電体表面にペロブスカイト型酸化物を形成することが できた.

(4) $\mathrm{SrPbO}_{3}$ の形成により, 集電体の粒界腐食を抑制し, 電 池寿命を約 2 倍とすることができた.

\section{文 献}

1）石踊 彰, 延山弘一，三谷 桂，寺田正幸，下浦一朗，新神戸 テクニカルレポート, No. 8, 19 (1998).

2）武政有彦，向谷一郎，吉山行男，福井浩一，桑野徹，福田 政寞, 御前博治, 宇渡和雄, 新神戸テクニカルレポート, No.9, 11 (1999).

3) Herbert Giess, Journal of Power Sources, 53, 31 (1995).

4) H. Tubakino, M. Tagami, S. Ioku, and A. Yamamoto, Metallugical and Materials Transactions, 27A, 155 (1996).

5）向谷一郎，坂本剛生，菊岡孝雄，山口豊，椿野晴繁，第 40 回電池討論会要旨集, 京都, p.99 (1999).

6) Wen-Hong Kao, Sandra L. Haberichter, and Kathryn R. Bullock, J. Electrochem. Soc., 139, 105 (1992).

7) 下浦一朗, 寺田正幸, 高島正之, 1998 年電気化学秋季大会 講演要旨集, 長岡, p.16 (1998).

8）寺田正幸，下浦一朗，特開平 8-17428。

9) 下浦一朗, 特開平 8-83616.

10）足立吟也，機器分析のてびき（増補改訂版）3，(株)化学同 人, 6 章, p.69 (1985).

11）佐藤太一，熱分析の基碟と応用（日本熱測定学会編），(株） 科学技術社, III-9 章, p.75 (1984).

12) R. J. Hill and I. C. Madsen, J. Electrochem. Soc., 131, 1486 (1984).

13) R. J. Hill and A. M. Jessel, J. Electrochem. Soc., 134, 1326 (1987).

14) D. Pavlov, I. Balkanov, T. Halachev, and P. Rachev, J. Electrochem. Soc., 136, 3189 (1989).

15）金村聖志，電池便覧（電池便覧編集委員会編），丸善，3.3.2 章 p.173 (1990).

16) D. Pavlov, J. Electrochem. Soc., 139, 3075 (1992).

17) Harvey E. Brown, LEAD OXIDE, International Lead Zinc Reserch Organization. Inc., p.31 (1985).

18) C. S. Lakshmi, On form and function, Batteries International, p.83 (1997).

19) HANS BODE, LEAD-ACID BATTERIES, John Wiley\& Sons, NewYork, p.316 (1977). 